6-1-1994

\title{
An Ultra-Sensitive Electrochemical Enzyme Immunoassay for Thyroid Stimulating Hormone in Human Serum
}

\author{
Zhengrong Yu \\ Cleveland State University \\ Yan Xu \\ Cleveland State University, y.xu@csuohio.edu \\ Michael P.C. Ip \\ Metro Health Medical Center
}

Follow this and additional works at: https://engagedscholarship.csuohio.edu/scichem_facpub

Part of the Chemistry Commons

How does access to this work benefit you? Let us know!

\section{Recommended Citation}

Yu, Zhengrong; Xu, Yan; and Ip, Michael P.C., "An Ultra-Sensitive Electrochemical Enzyme Immunoassay for Thyroid Stimulating Hormone in Human Serum" (1994). Chemistry Faculty Publications. 170. https://engagedscholarship.csuohio.edu/scichem_facpub/170

This Article is brought to you for free and open access by the Chemistry Department at EngagedScholarship@CSU. It has been accepted for inclusion in Chemistry Faculty Publications by an authorized administrator of EngagedScholarship@CSU. For more information, please contact library.es@csuohio.edu. 


\title{
An ultra-sensitive electrochemical enzyme immunoassay for thyroid stimulating hormone in human serum
}

\author{
ZHENGRONG YU, YAN XU ; and MICHAEL P.C. IP
}

\begin{abstract}
A sensitive heterogeneous electrochemical enzyme immunoassay has been developed for thyroid stimulating hormone (TSH) by modifying a commercially available two-site immunoenzymometric assay. $p$-Aminophenyl phosphate (PAPP) was used as the substrate of alkaline phosphatase, and hydrolysed to $p$-aminophenol (PAP). The amount of PAP produced from the assay was proportional to the amount of TSH in the sample. Detection of PAP was done by oxidative amperometry in a flow injection system. The working electrode was a glassy carbon electrode whose potential was held at $+325 \mathrm{mV}$ (vs Ag/AgCl). The amperometric detection of PAP required only $1 \mu \mathrm{l}$ of sample (the range of linearity: 50.0 fmol-100 pmol PAP, the limit of detection: $10.9 \mathrm{fmol}$ PAP). Intra-assay precision over the assay range of linearity $(0.02-$ $60 \mathrm{mIU} \mathrm{I}^{-1}$ or $0.02-60$ pIU TSH) showed a maximum RSD of $8.0 \%$, and a low detection limit of $0.01 \mathrm{mIU} 1^{-1}$ or $0.01 \mathrm{pIU}$ TSH. The study also indicates that this two-site electrochemical enzyme immunoassay correlates well with the Bio-Rad's immunoradiometric assay currently used in our medical center $(r=0.992$, slope $=1.53, n=43)$ and a highly sensitive immunochemiluminometric assay in the Nichols Institute $(r=0.986$, slope $=0.499, n=23)$.
\end{abstract}

Keywords: Thyroid stimulating hormone; ELISA; amperometric detection; flow injection analysis; p-aminophenyl phosphate.

\section{Introduction}

Thyroid stimulating hormone (TSH) is a glycoprotein $(28,300 \mathrm{Da})$ secreted by the basophilic cells of the anterior pituitary gland. TSH consists of two subunits, $\alpha$ and $\beta$, which are bound together noncovalently. Both subunits are necessary for its biological activity. TSH released from pituitary in response to a hypothalamic tripeptide, thyrotropin releasing hormone (TRH), stimulates the release of the thyroid hormones, triiodothyronine (T3) and thyroxine (T4). Through a negative feedback mechanism circulating thyroid hormones also regulate the hypothalamic secretion of TRH, or act directly on the pituitary gland by modulating its sensitivity to TRH. These regulatory mechanisms serve to maintain a dynamic balance of these hormones and their endocrine functions within cells and tissues [1,2].

The use of TSH and free T4 measurements has been gaining acceptance as a general diagnostic tool for evaluating thyroid disorders. The development of this approach and its application on the evaluation of hyperthyroidism (clinical or subclinical) has evolved according to the progressive improvement in the lower detection limits of TSH measurements (first, second and third generations). In thyroid disorders, TSH alterations generally precede $\mathrm{T} 3$ or T4 elevation (hyperthyroid) or suppression (hypothyroid). Each generation of analytical improvement on TSH was marked by its attainable improvements in limit of detection (LOD). The first-generation TSH assays were developed in the mid-1960s based on the use of competitive radioimmunoassay (RIA). These assays had LOD of $1-2 \mathrm{mIU} \mathrm{l}^{-1}$ [3-5] and were used primarily to differentiate hypothyroidism from normal. During the $1980 \mathrm{~s}$, the second-generation TSH immunoradiometric assays (IRMA) were introduced with the advent of monoclonal antibodies. Due to the greater binding constant of the mono- 
clonal antibodies, the IRMA assays had significantly improved LOD $\left(0.25-0.5 \mathrm{mIU} \mathrm{I}^{-1}\right)$ [6-9]. The extended lower detection limit of these assays provides the much needed sensitivity pertinent to the identification of hyperthyroid patients, where TSH is often lower than $0.1 \mathrm{mJU}^{-1}$ whereas $\mathrm{T} 3$ or $\mathrm{T} 4$ may remain normal or at lower limits of normal. However, the high relative standard deviation (RSD) in the range below $1 \mathrm{mIU} \mathrm{I}^{-1}$ somewhat limits its medical usefulness. The quest for high sensitivity and specificity TSH assays that not only differentiate thyroid disorder (in particular hyperthyroidism) from normal, but also assess the severity of hyperthyroidism has led to the recent development of the third-generation TSH immunochemiluminometric assays (ICMA). The use of monoclonal antibodies and modern nonisotopic detection technology in these assays has further improved the LOD to a range of $0.01-0.05 \mathrm{mIU}^{-1}[10-13]$. This improvement allows a better differentiation and separation of hyperthyroid subpopulation (including subclinical hyperthyroidism) from the normal non-thyroid illness control group, when applied to both in-patient and outpatient populations.

The coupled use of heterogeneous enzyme immunoassay with electrochemical detection in a flow injection system has been previously reported [14-17]. This approach combines the selectivity and specificity of an immunoassay with the sensitivity and low detection limit of electrochemical detection. The flow injection system provides an automatable linkage between the existing batch immunoassay and the detection system. Since the electrochemical signal is only related to the surface concentration of an analyte at the electrode, this method is not only sensitive but also well suited for small volume measurement.

In this study, a heterogeneous electrochemical enzyme immunoassay (EEIA) with the performance of the third-generation TSH assay has been developed by modifying a commercially available two-site immunoenzymometric assay (TANDEM-E TSH HS, Hybritech Incorporated, San Diego, CA). pAminophenyl phosphate (PAPP) was used as enzyme substrate and converted by alkaline phosphatase to $p$-aminophenol (PAP) at the end of immunoassay. Detection of PAP was done by oxidation amperometry in a flow injection system with as little as $1 \mu$ of sample. The assay had a linear dynamic range of 0.02
$60 \mathrm{mIU}^{-1}$ or $0.02-60 \mathrm{pIU}(\mathrm{LOD}=0.01 \mathrm{mIU}$ $1^{-1}$ or $\left.0.01 \mathrm{pIU}\right)$ and correlates well with both IRMA (Bio-Rad, Hercules, CA) and ICMA methods (Nichols Institute Diagnostics, San Juan Capistrano, CA), when applied to the analysis of TSH from serum samples collected from patients evaluated for thyroid disorders at our medical center.

\section{Materials and Methods}

\section{Reagents}

TANDEM ${ }^{8}$-E TSH HS immunoenzymometric assay kits were purchased from Hybritech Incorporated (San Diego, CA). The following components of the assay kit were used in this work: beads (coated with mouse monoclonal anti-hTSH IgG), antibody conjugate (mouse monoclonal anti-hTSH IgG conjugated to bovine alkaline phosphatase), zero diluent, TSH calibrators, TSH controls, and wash solution. Low-concentration TSH calibrators and controls were prepared by dilution of high-concentration calibrators and controls using the zero diluent.

PAP was obtained from Sigma (St Louis, MO). PAPP was synthesized from $p$-nitrophenyl phosphate (Boehringer Mannheim, Indianapolis, IN, USA) by a catalytic hydrogenation procedure as described in ref. [18]. Tris(hydroxymethyl) aminomethane $(>99.9 \%$ ) was from Aldrich (Milwaukee, WI). Magnesium chloride, sodium azide, and hydrochloric acid were from Fisher Scientific (Fair Lawn, NJ).

PAPP (4 mM), the enzyme substrate, was made up in a buffer solution containing: tris(hydroxymethyl) aminomethane, $0.1 \mathrm{M}$; magnesium chloride, $1 \mathrm{mM}$; and sodium azide, $0.2 \mathrm{~g} \mathrm{I}^{-1}$ at $\mathrm{pH} 9.0$. The same buffer solution was also used as the carrier fluid in flow injection analysis.

All solutions were prepared with ultrafiltered type I water (resistivity $>18 \mathrm{M} \Omega-\mathrm{cm}$ ) from a Barnstead NANOpure water system (Boston, MA).

\section{Apparatus}

The flow injection amperometric detection system used in this work was a BAS 480 chromatograph (Bioanalytical Systems, West Lafayette, IN). It consisted of an HPLC pump (PM-80), a custom injector with a 1- $\mu$ l sample loop, a flow cell (CC-5), an amperometric detector (LC-4B), a chart recorder or a data 
acquisition desk-top computer. A Teflon tubing with an inside diameter of $0.25 \mathrm{~mm}$ was used to connect the injector to the flow cell. A microbore column $\left(100 \times 1 \mathrm{~mm}, 3 \mu \mathrm{m} \mathrm{C}_{18}\right)$ was used between the pump and the injector to stabilize the fluid flow. The flow rate was set at $0.1 \mathrm{ml} \mathrm{min}^{-1}$.

A model 34010 Accuflex ${ }^{\mathrm{TM}}$ pipetting station (Micromedic Systems, Horsham, PA), a shaking incubator (GCA/Precision Scientific, Chicago, IL), BenchMate ${ }^{\mathrm{TM}}$ continuously adjustable pipettes (Nichiryo, Japan), a Vanlab ${ }^{\circledast}$ vortex mixer (Scientific Industries, Bohemia, NY), and a model 915 Accumet ${ }^{\otimes H}$ meter (Fisher Scientific) were also used in the present study.

\section{Assay procedure}

The general protocol of EEIA is given in Fig. 1. In duplicate, $200 \mu \mathrm{l}$ of zero diluent, TSH calibrator(s), TSH control(s), serum samples, and $100 \mu l$ of antibody conjugate were pipetted into the bottom of each labelled plastic test tube $(10 \times 55 \mathrm{~mm}$, Sarstedt, Germany). After vortexing, a single monoclonal anti-hTSH IgG coated bead was added into each tube. The assay tubes were incubated in a rack placed in the water bath of the shaking incubator and incubated with gentle rotation for $2 \mathrm{~h}$ at $32^{\circ} \mathrm{C}$. The bead within each tube was rinsed three times with the wash solution (at volumes of 2,1 and $1 \mathrm{ml}$, respectively) to remove any unbound material and non-specifically absorbed enzyme conjugate on the bead. After the liquid was aspirated, $200 \mu \mathrm{l}$ of substrate solution was added to each tube and incubated for $30 \mathrm{~min}$ at room temperature. At the end of reaction, the solution in each test tube was drawn into a syringe and $1 \mu \mathrm{l}$ of this solution in the loop injector was injected into the flow injection amperometric detection system. No reaction termination procedure is required. The oxidative current of PAP at various concentrations was used to plot the calibration curve.

\section{Results and Discussion}

\section{Amperometric detection in flow injection analysis}

The amperometric detector used for this work had a flow cell that consisted of three electrodes: a silver-silver chloride reference electrode, a glassy carbon working electrode, and a stainless steel auxiliary electrode. The oxidation current of PAP between the working electrode and the auxiliary electrode as a linear function of the concentrations of PAP at a fixed potential applied between the reference electrode and the working electrode was measured amperometrically within the flow cell. The fixed potential chosen for this work was $+325 \mathrm{mV}$, which was determined by repetitively injecting a single concentration of PAP into the detection system at different applied potentials. As shown in Fig. 2, the oxidation current of PAP reached a plateau at potentials greater than $+300 \mathrm{mV}$. The height of this plateau, or magnitude of the oxidation current, was directly proportional to the concentration of PAP. This proportionality was illustrated in Fig. 3 (PAP calibration plot). The dynamic range of the plot was from $50.0 \mathrm{fmol}$ to $100 \mathrm{pmol}$. The LOD was $10.9 \mathrm{fmol}$ as calculated using 2 times the signal-to-noise ratio.

Electrochemical detection is an interfacial rather than a bulk solution phenomenon. This has been well demonstrated by Fig. 3 . As the size of the sample loop was reduced from $20 \mu \mathrm{l}$ [15] to $1 \mu \mathrm{l}$, the lowest detectable amount of PAP was also lowered 20 times. This revealed the potential of electrochemical detection as a small volume detection technique.

\section{Incubation of p-aminophenyl phosphate}

Bovine alkaline phosphatase and its substrate, PAPP, were used in this assay. To study the substrate incubation time, the assay was carried out with three concentrations of TSH $\left(0,5\right.$ and $\left.60 \mathrm{mIU} \mathrm{I}^{-1}\right)$ and incubated with $4 \mathrm{mM}$ PAPP at room temperature for various periods of time. The result is shown in Fig. 4. From an earlier report [18], the apparent Michaelis constant, $K_{\mathrm{m}(\mathrm{app})}$, of bovine alkaline phosphatase for PAPP in a Tris buffer was determined as $56 \pm 5 \mu \mathrm{M}$. Since $4 \mathrm{mM}$ PAPP (as used in this assay) was $>70$ times $K_{\mathrm{m} \text { (app) }}$, zeroorder enzyme kinetics was expected. However, a plateau of peak current was reached after 20 min of incubation in this study. The occurrence of the plateau was probably due to the rate of air-oxidation of PAP equaling the rate of PAP production by the enzyme reaction as discussed in 15 and 18. Consequently, the precise timing for detection of PAP was not critical after 20 min of incubation, which suggested that the use of a quench reagent was not necessary.

The blank current responses shown in Fig. 4 


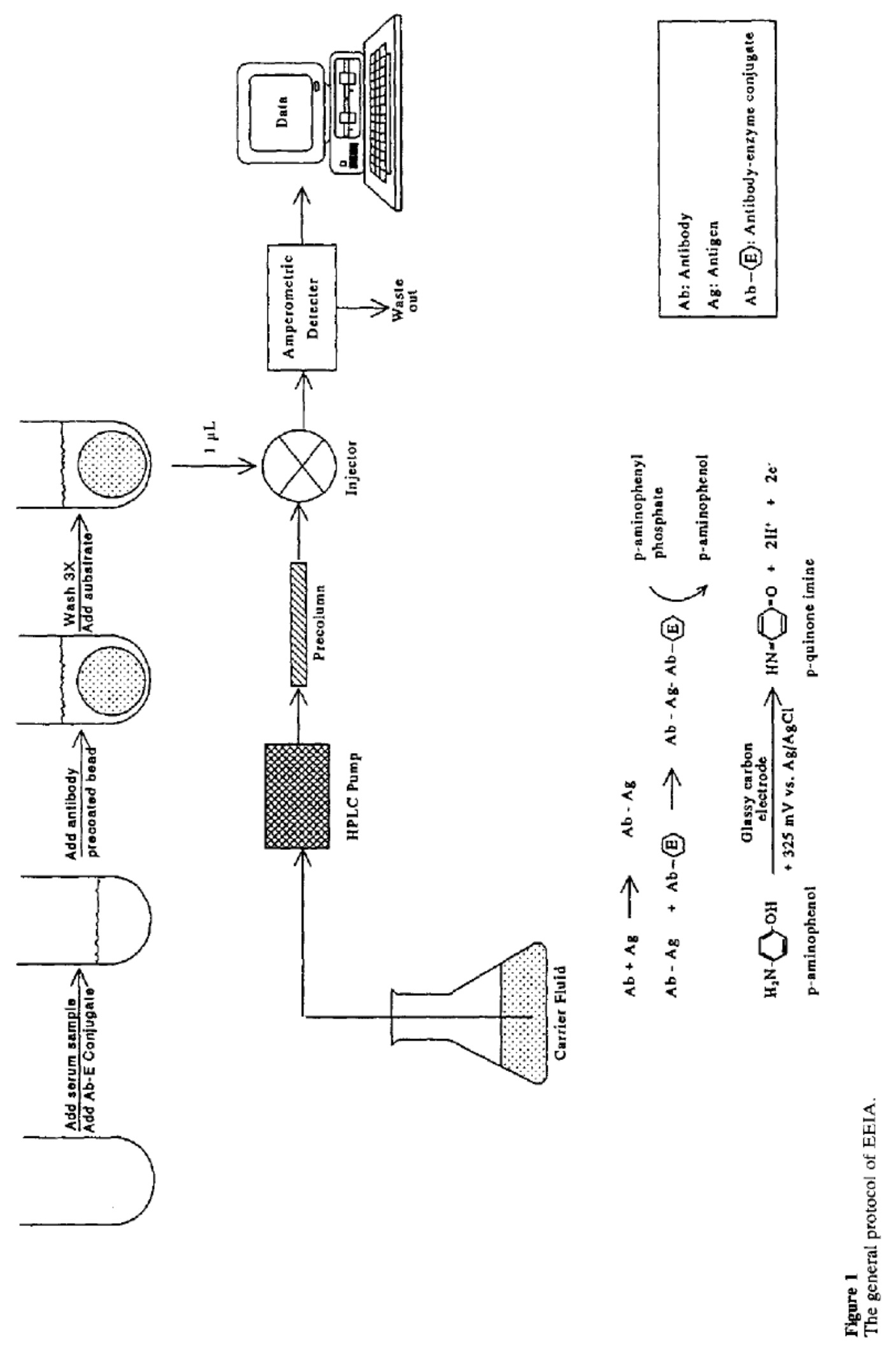




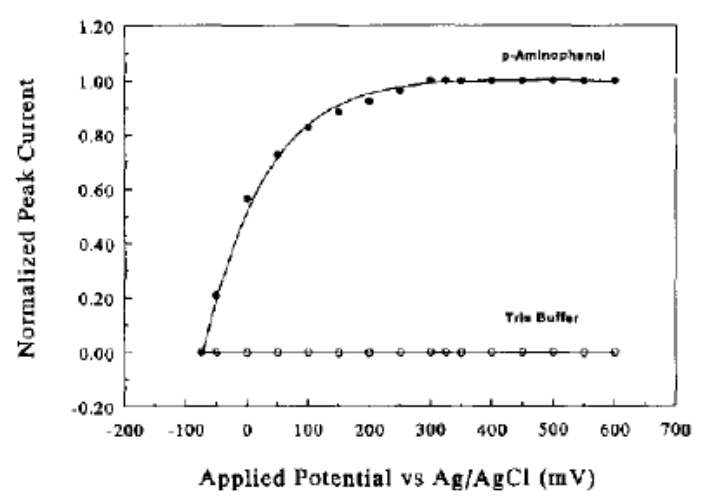

Figure 2

The hydrodynamic voltammogram of $1 \times 10^{-5} \mathrm{M}$ of PAP in $0.1 \mathrm{M}$ Tris buffer at $\mathrm{pH} 9.0$.

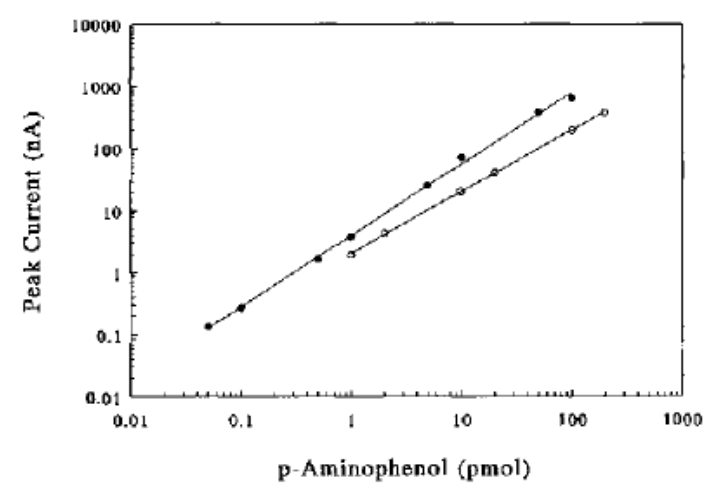

Figure 3

The calibration plots of PAP in $0.1 \mathrm{M}$ Tris buffer at $\mathrm{pH}$ 9.0. Applied potential: $+325 \mathrm{mV}$ vs $\mathrm{Ag} / \mathrm{AgCl}$ reference; []: $1 \mu$ l sample loop; [O]: $20 \mu$ l sample loop (from ref. 15).

were attributable to the non-specific adsorption of the antibody-enzyme conjugate that converted PAPP to PAP, and the presence of a nonfaradaic signal that coregistered with the oxidation current of PAP $[15,19]$.

\section{Analytical performance}

The analytical performance of the EEIA is summarized in Table 1. This method gave good

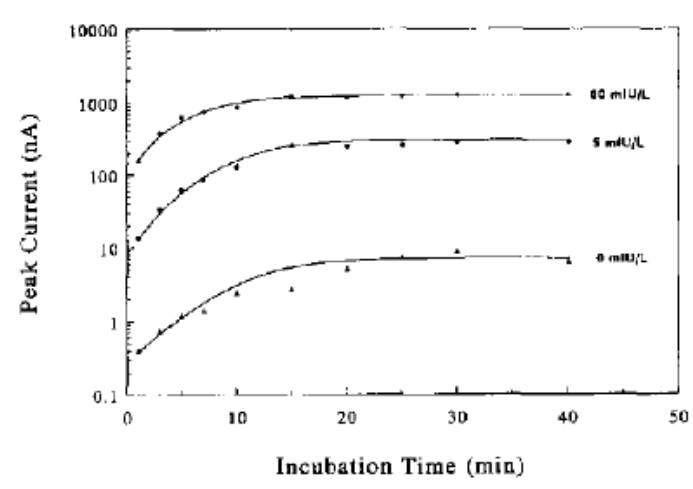

Figure 4

The incubation of $4 \mathrm{mM}$ of PAPP with alkaline phosphate at the end of EEIA.

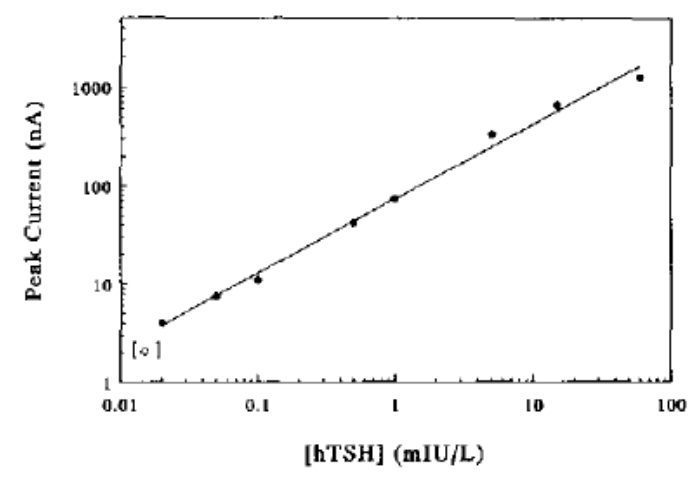

Figure 5

Peak current vs [hTSH]. [O] denotes the zero diluent ( $n=$ 28). Intercept $=1.871$, slope $=0.757$, and $r=0.997$.

intra-assay precision (RSDs $\leq 8.0 \%$ ) over its entire linear dynamic range of $0.02-60 \mathrm{mIU} \mathrm{l}^{-1}$ or $0.02-60$ pIU TSH (Fig. 5). The LOD of the assay was $0.01 \mathrm{mIU}^{-1}$ or $0.01 \mathrm{pIU}$ TSH that was defined as the mean signal of 28 replicates of zero calibrator plus 2 times the standard deviation. This LOD (expressed in concentration) has been improved 10 -fold over that of the TANDEN ${ }^{3}$-E TSH HS immunoenzymometric assay of Hybritech. The assay has displayed the characteristics of a third-gener-

Table 1

Analytical performance of TSH EEIA

\begin{tabular}{lcccc}
\hline hTSH calibrator (mIU l $\left.^{-1}\right)$ & $n$ & Mean (nA) & SD (nA) & RSD (\%) \\
\hline 0.00 & 28 & 2.04 & 0.16 & 8.0 \\
0.02 & 2 & 4.08 & 0.28 & 6.9 \\
0.05 & 2 & 7.55 & 0.28 & 3.7 \\
0.1 & 2 & 11.1 & 0.71 & 6.4 \\
0.5 & 2 & 41.9 & 0.85 & 2.0 \\
1 & 2 & 73.9 & 2.3 & 3.1 \\
5 & 2 & 335 & 7.8 & 5.3 \\
15 & 2 & 661 & 34 & 6.7 \\
60 & 2 & 1276 & 85 & 6.7 \\
\hline
\end{tabular}


ation TSH assay (e.g. ICMA of Nichols Institute).

\section{Comparison of methods}

In our EEIA procedure two TSH calibrators and two TSH controls within the calibration range were employed for routine analysis. Since there was no internationally accepted TSH reference standard available, we could not study the accuracy of the method developed. However, it will be helpful to compare the analytical performance of the developed method with the commercial TSH assays. Therefore, the analytical performance of our EEIA procedure was further evaluated by comparing the analytical data of in- and outpatient specimens with those from the CoTube $^{\mathrm{TM}}$ TSH IRMA assay procedure (BioRad) (calibration range: $0.1-100 \mathrm{mIU} \mathrm{l}^{-1}$ TSH) that is curently used in our clinical laboratory.

Upon collection, serum samples were split. Samples used for CoTube ${ }^{\mathrm{TM}}$ TSH IRMA assay were refrigerated at $4^{\circ} \mathrm{C}$. Analysis was performed within $36 \mathrm{~h}$. Samples saved for EEIA were quickly frozen at $-70^{\circ} \mathrm{C}$ until analysis. On 43 patients' samples, a good correlation was observed $(r=0.992)$ at TSH concentrations $>0.1 \mathrm{mIU} \mathrm{l}^{-1}$ (Fig. 6). Samples with values of $<0.1 \mathrm{mIU} 1^{-1}$ TSH (below the calibration range of CoTube ${ }^{\mathrm{TM}}$ IRMA TSH assay) were sent to the Nichols Institute. The measurements were done by the third-generation high sensitive TSH ICMA (calibration range: $0.01-55 \mathrm{mIU}^{1}{ }^{1}$ ). The results plotted in Fig. 7 show a correlation coefficient of 0.986 $(n=23)$ between our EEIA and the TSH ICMA.

Apparently biases existed among the data obtained from EEIA, ICMA and IRMA (Figs 6 and 7). These biases were probably attributable to one or several factors, such as the inherent differences in sensitivity among the final detection methods [18], the differences in the assigned values of the calibrators from the threc manufacturers $[20,21]$, and the specificity of the antibodies used in these assays [22].

\section{Other considerations}

Although this work was done by manual operation, the assay procedure can be automated when coupled to an automated immunoassay analyser (e.g. PHOTON Era, Hybritech), using a flow-injection amperometric

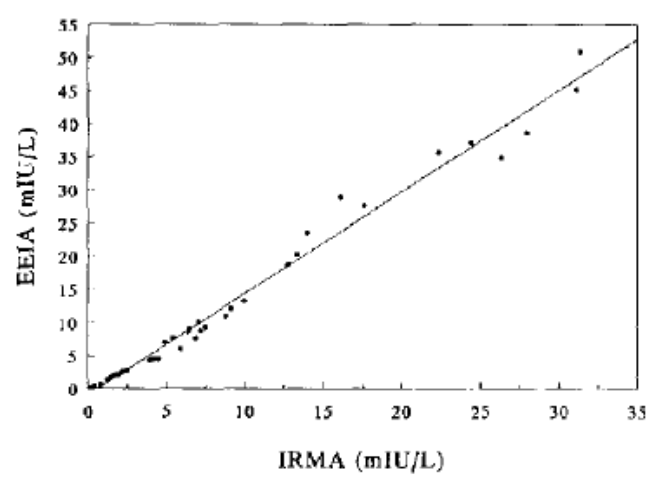

Figure 6

Method comparison. TSH concentrations in 43 patients' sera were assayed by both our EElA and Bio-Rad's IRMA. Slope $=1.53$, and $r=0.992$.

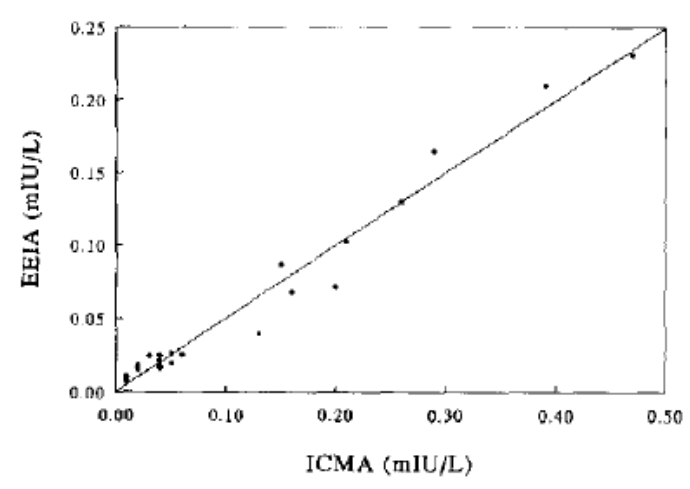

Figure 7

Method comparison. TSH concentrations in 23 patients' sera were assayed by both our EEIA and ICMA of Nichols Institute. Slope $=0.499$, and $r=0.986$.

detection system with an auto-sampler (e.g. BAS 480 and BAS CMA/200, Bioanalytical Systems), and a PC controller.

The amperometric detection is a sensitive detection technique for enzyme immunoassay and requires as little as $1 \mu$ injected sample for detection. However, the advantage of amperometric detection as a small volume detection technique has not yet been fully exploited. For example, if the volume of antibody coated bead is reduced to one quarter of its original volume, it will enable us not only to reduce the size of the patient's sample (an important consideration when multiple endocrine tests are required from pediatric specimens), but also to limit the reagent cost for the analysis.

\section{Conclusions}

This method provides a fast, sensitive and reliable measurement of TSH in human serum. 
It is clinically useful for evaluating hyperthyroid patients for whom an accurate determination of TSH $<0.1 \mathrm{mIU}^{-1}$ is required. The ability of flow injection amperometry to detect low concentrations of analyte in small volumes may help limit reagent cost and sample consumption.

\section{References}

[1] M. Fernandez-Ulloa and H.R. Maxon III, in Clinical Chemistry: Theory, Analysis and Correlation, 2 nd edn (L. Kaplan and A.J. Pesce, Eds), pp. 620-638. CV Mosby, St Louis, MO (1989).

[2] J.G. Pierce, Endocrinology 89, 1331-1344 (1971).

[3] W.D. Odell, J.F. Wilber and W.E. Paul, J. Clin. Endocrinol. 25, 1179-1188 (1965).

[4] R.E. Wehmann, H.A. Rubenstein, M.M. Pugeot and B.C. Nisula, South. Med. J. 76, 969-976 (1983).

[5] R.E. Wehmann and B.C. Nisula, Crit. Rev. Clin. Lab. Sci. 20, 243-283 (1984).

[6] J.H. McBride, R.V. Thibeault and D.O. Rodgerson, Clin. Chem. 31, 865-1867 (1985).

[7] V. Van Heyningen, S.R. Abbott, S.G. Daniel, L.J. Ardisson and E.C. Ridgway, Clin. Chem. 33, 13871390 (1987).

[8] H.Y. Lee, A.E. Pekary, V.P. Smith, J. Sladek and J.M. Hershamn, Clin. Chem. 33, 1223-1226 (1987).
[9] M.K. Gupta, K. Seifarth, S.D. Deodhar and O.P. Schumacher, J. Clin. Lab. Anal. 1, 124-128 (1987).

[10] A.J. Parnham and I.F. Tarbit, Clin. Chem. 33, 14211424 (1987).

[11] T.A. Wilkins, G. Brouwers, J.C. Mareschal and C.L. Cambiaso, Clin. Chem. 34, 1749-1752 (1988).

[12] C.A. Spencer, J.S. LoPresti, A. Patel, R.B. Guttler, A. Eigen, D. Shen, D. Gray and J.T. Nicoloff, $J$. Clin. Endocrinol. Metab. 70, 453-460 (1990).

[13] D.S. Ross, G.H. Daniels and D. Gouveia, J. Clin. Endocrinol. Metab. 71, 764-769 (1990).

[14] K.R. Wehmeyer, H.B. Halsall and W.R. Heineman, Anal. Chem. 58, 135-139 (1986).

[15] Y. Xu, H.B. Halsall and W.R. Heineman, J. Pharm. Biomed. Anal. 7, 1301-1311 (1989).

[16] E.P. Gil, H.T. Tang, H.B. Halsall, W. R. Heineman and A.S. Misiego, Clin. Chem. 36, 662-665 (1990).

[17] Y. Xu, H.B. Halsall and W.R. Heincman, Clin. Chem. 36, 1941-1944 (1990).

[18] R.Q. Thompson, G.C. Barone III, H.B. Halsall and W.R. Heinman, Anal. Biochem. 192, 90-95 (1991).

[19] Y. Xu, H.B. Halsall and W.R. Heineman, Electroanalysis 4, 33-40 (1992).

[20] O.P. Bormer, E. Paus and K. Hustad, Scand. J. Clin. Lab. Invest. 51 (Suppl. 206), 12-20 (1991).

[21] J.M. Van Emon and V. Lopez-Avila, Anal. Chem. 64, 79A-88A (1992).

[22] R. Jefferis and I. Deverill, in Principles and Practice of Immunoassay (C.P. Price and D.J. Newman, Eds), pp. 1-18. Stockton Press, New York, NY (1991).

[Received for review 18 August 1993; revised manuscript received 2 December 1993] 